\title{
Reduction of Lesion in Injured Rat Spinal Cord and Partial Functional Recovery of Motility after Bone Marrow Derived Mesenchymal Stem Cell Transplantation
}

\author{
Omurilik Hasarlı Szçanlarda Kemik İliği Kaynaklı Mezenkimal Kök \\ Hücre Transplantasyonu Sonrasi Lezyonda Azalma ve Harekette Kismi \\ Isslevsel İyileşme
} \author{
Murat MUSLUMAN ${ }^{3}$, Erdinc CIVELEK ${ }^{2}$ \\ ${ }^{1}$ Kocaeli University, Faculty of Medicine, Department of Stem Cell, Kocaeli, Turkey \\ ${ }^{2}$ Baskent University, Faculty of Medicine, Department of Neurosurgery, Istanbul, Turkey \\ ${ }^{3}$ M.H. Sisli Etfal Education and Research Hospital, Department of Neurosurgery, Istanbul, Turkey
}

Erdal KARAOZ ${ }^{1}$, Serdar KABATAS ${ }^{2}$, Gokhan DURUKSU ${ }^{1}$, Alparslan OKCU ${ }^{1}$, Cansu SUBASI ${ }^{1}$, Birol AY ${ }^{1}$,

Correspondence address: Erdal KARAOZ / E-mail: ekaraoz@hotmail.com

\begin{abstract}
AIM: This study aimed to analyze the effect of rat bone marrow-mesenchymal stem cells (rBM-MSCs) delivery on lesion site after spinal cord injury, and to observe the functional recovery after transplantation.

MATERIAL and METHODS: MSCs were isolated from rat femurs and tibias. The experimental rat population was divided into four groups: only laminectomy (1); laminectomy+trauma (2); laminectomy+trauma+PBS (3); laminectomy+trauma+MSCs (4). Their motility were scored regularly. After 4-weeks, rats were sacrificed, and their spinal cords were examined for GFP labeled rBM-MSCs by immunostainings.

RESULTS: In the early posttraumatic period, the ultrastructures of spinal cord tissue were preserved in Group 4. The majority of cells forming the ependymal region around the central canal were found to be MSCs. The gray-and-white-matter around the ependymal region were composed of Nestin+/GFAP+ cells, with astrocytic-like appearance. The scores showed significant motor recovery in Group 4, especially in hind limb functions. However, no obvious change was observed in other groups.

CONCLUSION: The increase Nestin+/GFAP+ cells in the gray-and-white-matter around the ependymal region could indicate the potential to self-renew and plasticity. Thus, transplantation of rBM-MSCs might be an effective strategy to improve functional recovery following spinal cord trauma. In conclusion, molecular factors in cell fate decisions could be manipulated to enhance reparative potential of cell-based therapy. KEYWORDS: Bone marrow, Mesenchymal stem cells, Spinal cord injury, Functional recovery, Rats
\end{abstract}

öz

AMAÇ: Bu çalışmada omurilik hasarı sonrası sıçan kemik iliği-mezenkimal kök hücrelerinin (sKi-MKH) lezyon yerindeki etkisini analiz etmek ve transplantasyon sonrası işlevsel iyileşmeyi gözlemlemek amaçlandı.

YÖNTEM ve GEREÇLER: MKH'ler sıçan femur ve tibialarından izole edildi. Deney sıçanları dört gruba ayrıldı: sadece laminektomi (1), laminektomi + travma (2); laminektomi + travma + PBS (3); laminektomi + travma + MKH'ler (4). Sıçanların hareketleri düzenli olarak skorlandı. Dört hafta sonra sıçanlar sakrifiye edildi, omurilikleri immün boyamayla GFP işaretli sKi-MKH'lerle incelendi.

BULGULAR: Erken posttravmatik dönemde, Grup 4'teki omurilik dokusu ultrastrüktürel olarak korundu. Santral kanalın etrafındaki ependimal bölgeyi oluşturan hücrelerinin çoğu MKH'ler olarak saptandı. Ependimal bölgenin etrafındaki gri ve ak maddeler astrositik görünümlü Nestin+/ GFAP+ hücrelerden oluşmuştu. Grup 4'te özellikle arka bacak fonksiyonlarında motor iyileşme belirgindi. Buna karşın, diğer gruplarda belirgin değişiklik izlenmedi.

SONUÇ: Ependimal bölgenin etrafındaki gri ve ak maddede Nestin+/GFAP+ hücrelerin artışı kendini yenileme ve plastisite potansiyellerini gösterebilir ve sKi-MKH'lerin transplantasyonu spinal kord travması sonrası fonksiyonel iyileşmede etkili bir strateji olabilir. Sonuç olarak, moleküler faktörler hücre kaderini belirleyen hücre tabanlı tedavinin onarıcı potansiyelini artırmak için uygulanabilir.

ANAHTAR SÖZCÜKLER: Kemik iliği, Mezenkimal kök hücreleri, Omurilik yaralanması, İşlevsel iyileşme, Sıçanlar 


\section{INTRODUCTION}

Spinal cord injury $(\mathrm{SCl})$ is a very serious and common health problem, and it is still not curable functionally. Due to the non-responsive environment of the injured spinal cord, axon regeneration does not occur $(20,22)$. Besides, the loss of function after $\mathrm{SCl}$ might be from both the primary mechanical insult and the subsequent, multifaceted secondary degenerative response. However, some experimental studies in last decades proved that the injured spinal cord could be restored $(7,18)$. Nowadays, stem cell based therapy is promising some valuable strategies for functional recovery of the injured spinal cord. In this context, mesenchymal stem cells were used in addition to neural progenitor stem cells for functional recovery $(12,13)$.

We previously reported that rat bone-marrow-derived mesenchymal stem cells (rBM-MSCs) expressed myogenic (desmin, myogenin, myosinlla, and asma), neurogenic (eno2, MAP2a,b, c-fos, nestin, gfap and betalll-tubulin), and osteogenic (osteonectin, osteocalcin, osteopontin, runx2,BMP-2, BMP-4 and type-I collagen) markers without inducing differentiation (9). The expression of these genes could be the reason of rBM-MSCs' predisposition of multilineage differentiation, including neurogenic lineages both in vitro and in vivo. Respectively, rBM-MSCs have crucial importance to restore some disorders including neural defects.

Our aim in this study was to analyze the healing effect of rBMMSCs on lesion site after spinal cord injury and to observe the degree of functional recovery in motility after transplantation.

\section{MATERIAL and METHODS}

\section{Animals}

The $\mathrm{SCl}$ study included 18 female, nonpregnant Wistar albino rats about 2 months old with a weight of $200-300 \mathrm{~g}$. In the first step of the study, six rats were sacrificed and their femurs and tibias were excised in order to obtain MSCs. The remaining rats were divided into four groups (3 rats per group): only laminectomy (Group 1); laminectomy+trauma (Group 2); laminectomy+trauma+PBS (Group 3); laminectomy+ trauma+MSCs (Group 4). Rats were sacrificed 4 weeks after transplantation. The experimental design and all procedures were approved by the Ethics Committee of Kocaeli University.

\section{Isolation and Culture of rBM-MSCs}

Isolation and culture of rBM-MSCs were performed as previously described (9). Under sterile conditions, both rat femur and tibiae were excised, and the bone marrow was flushed with MEM-Earle medium supplemented with $15 \%$ FBS, 1\% Penicillin/Streptomycin (Gibco Invitrogen, Life Technologies, Paisley, UK). The supernatant containing thrombocytes and erythrocytes was discarded, and the cell pellet was resuspended in MEM medium. The cells were seeded on plastic tissue culture flasks and incubated for 3 days. The MSCs were isolated based on their ability to adhere on plastic. Fresh medium was added to remove the unattached cells. After plate reached $70-80 \%$ confluency, the cells were passaged using $0.25 \%$ trypsin-EDTA solution (Gibco Invitrogen) after washing with $\mathrm{Ca}^{2+}-\mathrm{Mg}^{2+}$ free phosphatebuffered saline (PBS; Gibco Invitrogen).

\section{Flow Cytometry}

Undifferentiated SCs were subjected to flow cytometry analysis to confirm that rBM-MSCs maintain their phenotypic characteristics after growth in culture. Three surface markers of rBM-MSCs at passages $3\left(P_{3}\right)$ were assayed with antibodies against the following rat antigens: CD29 (Integrin $\beta_{1}$ chain; Ha2/5;FITC), CD45 (PE), and CD90 (Thy-1/Thy-1.1-FITC), and their isotype controls (IgG2a $\left.{ }_{k} ; \mathrm{FITC}\right)$. All of the antibodies were supplied by Becton Dickinson (BD Biosciences, San Diego, USA). Flow cytometry was performed using a FACSCalibur (BD Biosciences) device. The data were analyzed with Cell Quest software (BD Biosciences).

\section{Immunostainings}

The immunohistochemistry studies on the $\mathrm{P}_{3}$ cells were performed as previously described (9), and the list of primary antibodies is given in Table I. Samples were fixed in ice-cold methanol for $10 \mathrm{~min}$ and treated with $0.025 \%$ Triton X-100 (Merck, Darmstadt, Germany) for permeabilization. Cells were incubated with $1.5 \%$ blocking serum solution (Santa Cruz Biotechnology, Heidelberg, Germany) for $30 \mathrm{~min}$ at $37^{\circ} \mathrm{C}$ and incubated overnight at $4^{\circ} \mathrm{C}$ with the primary antibodies after washing with PBS. Samples were incubated with appropriate secondary antibodies for $25 \mathrm{~min}$ and covered with mounting medium containing DAPI (Santa Cruz Biotechnology). The mounted cells were examined under fluorescence microscope (Leica DMI 4000B, Wetzlar, Germany).

\section{In Vitro Differentiation}

The in-vitro studies of adipogenic, osteogenic, and neurogenic differentiations were performed according to the methods described previously by Karaoz et al. (9).

The adipogenic differentiation was performed by incubation of MSCs in Standard culture media with supplementations ( $0.5 \mathrm{mM}$ isobutyl-methylxanthine, $10^{-6} \mathrm{M}$ dexamethasone, 10 $\mu \mathrm{g} / \mathrm{ml}$ insulin, $200 \mu \mathrm{M}$ indomethacin) for two weeks.

For osteogenic differentiation, the cells were incubated in osteogenic differentiation medium (standard culture media supplemented with $100 \mathrm{nM}$ dexamethasone, $0.05 \mu \mathrm{M}$ ascorbate-2-phosphate, $10 \mathrm{mM} \beta$-glycerophosphate) for four weeks.

Neurogenic differentiation was performed by incubating the cell in culture medium supplemented with $10 \mathrm{ng} / \mathrm{ml}$ basic fibroblast growth factor, $10 \mathrm{ng} / \mathrm{ml}$ epidermal growth factor, $10 \mathrm{ng} / \mathrm{ml}$ Brain derived neurotrophic factor, $0.5 \mathrm{mM}$ isobutylmethylxanthine for 24-72 $\mathrm{h}$.

\section{Labeling with GFP of Mesenchymal Stem Cells}

pGFP (Clontech, Palo Alto, CA, USA), was transfected by electroporation (Neon Transfection System, Invitrogen, 
Table I: Immunocytochemical Properties of rBM-MSCs

\begin{tabular}{|c|c|c|c|}
\hline Antibody/Marker & Dilution & Source & rBM-MSCs \\
\hline CD 31 (M-20) & $1: 100$ & Santa Cruz & $\varnothing$ \\
\hline CD 34 (C-18) & $1: 150$ & Santa Cruz & $\varnothing$ \\
\hline CD $45(\mathrm{H}-230)$ & $1: 150$ & Santa Cruz & $\varnothing$ \\
\hline CD $71(\mathrm{~K}-20)$ & $1: 150$ & Santa Cruz & $\varnothing$ \\
\hline CD105 (M-20) & $1: 100$ & Santa Cruz & + \\
\hline c-Fos (4) & $1: 50$ & Santa Cruz & + \\
\hline Collagen II (2B1.5) & Prediluted & Thermo Scientific & + \\
\hline Collagen la1 (D-13) & $1: 50$ & Santa Cruz & + \\
\hline $\begin{array}{l}\text { Beta-tubulin (KMX-1) } \\
\text { Beta-tubulin }\end{array}$ & $\begin{array}{l}1: 50 \\
\text { Prediluted }\end{array}$ & $\begin{array}{l}\text { Milipore } \\
\text { Thermo Scientific }\end{array}$ & + \\
\hline Nestin (Rat-401) & $1: 50$ & Santa Cruz & + \\
\hline Vimentin (C-20) & $1: 100$ & Santa Cruz & + \\
\hline $\begin{array}{l}\text { Desmin }(\mathrm{H}-76) \\
\text { Desmin (D33) }\end{array}$ & $\begin{array}{l}1: 50 \\
\text { Prediluted }\end{array}$ & $\begin{array}{l}\text { Santa Cruz } \\
\text { Thermo Scientific }\end{array}$ & $+^{1}$ \\
\hline Fibronectin (EP5) & $1: 100$ & Santa Cruz & + \\
\hline Asma & $1: 800$ & Thermo Scientific & + \\
\hline Actin $(C-2)$ & $1: 50$ & Santa Cruz & + \\
\hline Osteocalcin (FL-100) & $1: 50$ & Santa Cruz & + \\
\hline $\begin{array}{l}\text { Osteonectin (SPARC) } \\
\text { SPARC }(\mathrm{H}-90)\end{array}$ & $\begin{array}{l}1: 50 \\
1: 50\end{array}$ & $\begin{array}{l}\text { Milipore } \\
\text { Santa Cruz }\end{array}$ & + \\
\hline Osteopontin (AKm2A1) & $1: 50$ & Santa Cruz & $+^{1}$ \\
\hline MAP 2a,b (AP20) & Prediluted & Thermo Scientific & + \\
\hline GFAP & Prediluted & Thermo Scientific & + \\
\hline Beta3-tubulin (2Q121) & $1: 50$ & Santa Cruz & + \\
\hline NSE/eno2 & $1: 500$ & Milipore & + \\
\hline HNK-1ST (E-20) & $1: 50$ & Santa Cruz & $\varnothing$ \\
\hline Cytokeratin 18 & $1: 50$ & Santa Cruz & $\varnothing$ \\
\hline vWF (F8/86) & $1: 50$ & Santa Cruz & $\varnothing$ \\
\hline CD146 & $1: 300$ & Abcam & +1 \\
\hline Ki67 & $1: 200$ & Abcam & + \\
\hline BrdU & $1: 500$ & Thermo Scientific & + \\
\hline
\end{tabular}

$+=$ Positive; $\boldsymbol{\varnothing}=$ no expression; $-/+=$ weak. ${ }^{1}=10-20 \%$ positive.

Carlsbad, CA, USA) with respect to the instructions provided by manufacturer. The transformed cells were cultured in $1 \mathrm{ml}$ MEM-medium with 15\% FBS. After $48 \mathrm{~h}$ of incubation, the cells were selected with respect to resistance against G418 $(200 \mu \mathrm{g} / \mathrm{ml})$.

\section{Surgical Procedure and Cell Transplantation}

For skin preparation of T10-11 spinal cord surgery, lumbar laminectomy of tracer injection, dermal surface of the related regions was cleared by hair razor, and the skin was washed by antibacterial soap followed with betadine and $70 \%$ ethanol application (2). After an overnight fast with unrestricted access to water, all 12 rats were anesthetized with intramuscular ketamine $(50 \mathrm{mg} / \mathrm{kg})$ and xylazine $(5 \mathrm{mg} / \mathrm{kg}$ ) prior to surgery.
Under dissection stereo microscope; $3 \mathrm{~mm}$ long laminectomy, encompassing the caudal end of T10 vertebra and the rostral end of $\mathrm{T} 11$ vertebra, was performed. For $\mathrm{SCl}$ groups (total: $\mathrm{n}=12$ ), a severe T10-T11 contusive injury was introduced by dropping the impounder rod $(1 \mathrm{~g})$ from a height of $50 \mathrm{~mm}$.

GFP labeled rBM-MSCs $\left(3 \times 10^{5}\right.$ cells $\left./ 5 \mu \mathrm{L}\right)$ were transplanted into the injured spinal cord via Hamilton syringe (Hamilton company, Reno, NV) connected to a syringe pump (KD Scientific Inc., Holliston, MA, USA) for 5 min, respectively. PBS group received $5 \mu \mathrm{L}$ of $\mathrm{PBS}$ at the injured spinal cord with the same technique. The needle was removed $10 \mathrm{~min}$ after subcutaneous transplantation, and muscle \& skin layers were closed in layers. The bladders of $\mathrm{SCl}$ rats will evacuate twice daily during the entire study. 


\section{BBB Scoring-Functional Tests}

Functional tests were performed using the Basso, Beattie and Bresnahan (BBB) locomotor rating scale at pre-surgery, at days 1, 7, 14, 21, and 28 postinjury (p.i.). Two independent, blinded examiners observed each animal for $4 \mathrm{~min}$. Hindlimb movements were recorded by video camera and locomotor functions were assessed (1). The BBB scores were presented as mean \pm standard error.

\section{Tissue Harvesting and Immunohistochemical Examination}

At the end of 4 weeks, rats were anesthetized with ketamine (75 mg/kg, i.p.) and xylazine ( $20 \mathrm{mg} / \mathrm{kg}$, i.p.), and transcardially perfused with saline ( $150 \mathrm{ml} /$ per animal) and followed with $4 \%$ neutral buffered paraformaldehyde in $0.1 \mathrm{~mol} / \mathrm{L} \mathrm{PBS,} \mathrm{pH} \mathrm{7.4.}$ $1.0 \mathrm{~cm}$ spinal cord segment encompassing the injury site was removed, the tissues were post-fixed in 4\% paraformaldehyde approximately $24 \mathrm{~h}$ and then embedded in paraffin. Five longitudinal serial sections, each $5 \mu \mathrm{m}$ thick, were taken from each paraffin embedded spinal cord samples.

To perform cell tracing after injection of the GFP labeled rBMMSCs, an immunofluorescence double staining protocol was performed on sections. Slides were deparaffinized with two changes of xylene for $5 \mathrm{~min}$ each and rehydrated in a series of graded alcohol solutions. Sections were antigen retrieved using a steamer-citrate buffer antigen retrieval method. Endogenous peroxidases were inhibited by incubation with fresh $3 \% \mathrm{H}_{2} \mathrm{O}_{2}$ in PBS buffer. Nonspecific staining was blocked with the mixture of two different serum at $1.5 \%$ in PBS for $30 \mathrm{~min}$ at room temperature (RT). Afterwards, the sections were incubated in a mixture of two primary antibodies in a pairwise fashion with the mouse monoclonal anti-GFP antibody (sc-9996, Santa Cruz, Heidelberg, Germany) and vimentin (sc-7557, Santa Cruz), beta3-tubulin (sc-69965, Santa Cruz) or nestin (sc-33677, Santa Cruz) or with GFAP (MS280-R1, Thermo Scientific, NeoMarkers, Fremont, CA, USA) at appropriate dilutions in antibody dilution buffer for $1 \mathrm{~h}$ at RT. The sections were incubated in a mixture of two fluorescent conjugated secondary antibodies, which included the goat anti-mouse FITC (sc-2010, Santa Cruz) for the GFP antibody, donkey anti-goat TR (sc-2783, Santa Cruz) for vimentin, goat anti-mouse TR(sc-2781, Santa Cruz) for GFAP, beta3-tubulin and nestin at the dilution of 1:50 in PBS buffer for $30 \mathrm{~min}$ at room temperature and were mounted with mounting medium containing DAPI (Santa Cruz). The mounted cells were examined under a fluorescence microscope.

\section{Statistical Analyses}

All experiments were repeated a minimum of three times. All data presented as mean \pm standard error. All statistical analyses were performed using SPSS 10.0 (SPSS Inc., Chicago, IL, USA). Data were analyzed using one-way ANOVA. Differences between groups were regarded as statistically significant when $P<0.05$.

\section{RESULTS}

\section{Culture of rBM-MSC}

MSCs attached to the culture flasks sparsely and displayed a fibroblast-like, spindle-shaped morphology during the initial days of incubation. Following 3-4 days of incubation, proliferation started and the cells gradually grew into small colonies (Figure 1A,B). As growth continued, adjacent colonies interconnected with each other and a monolayer confluence was obtained after 12 to 15 days of incubation. In later passages, MSCs exhibited large, flattened or fibroblast-like morphology (Figure 1C,D) and did not change throughout 25 passages. Tests for bacterial and mycoplasm contamination were negative and the viability was higher than $95 \%$. rBMMSCs expressed CD29 and CD90, but not CD45 (Figure 1E) and maintained their phenotype in the following passages.

\section{Immunostaining of rBM-MSCs}

Immunohistochemical studies were performed to characterize the progeny of the rBM-MSCs, by using a large panel of antibodies specific to known antigens (Figure 2, 3). Immune reactivity profile for rBM-MSCs is shown in Table I. Under described standard culture conditions, asma (Figure 2A), beta-tubulin (Figure 2B, 3A), GFAP (Figure 2C), beta-actin (Figure 2E,3D), osteocalcin (Figure 2F), c-fos (Figure 2G), type-II collagen (Figure $2 \mathrm{H}$ ), osteonectin (Figure $2 \mathrm{I}$ ), vimentin (Figure 3B), fibronectin (Figure 3C), CD105, CD146, type-I collagen, osteopontin, nestin (data not shown) were expressed. rBM-MSCs did not express some surface markers including von Willebrand Factor (vWF), Cytokeratin (CK) 18, CD31 (endothelial marker), CD34 (Figure 2D), CD45 (hematopoietic marker) and CD71 (Table I).

\section{Differentiation potential of rBM-MSCs}

rBM-MSCs at passage 3 were used in the adipogenic differentiation experiments, in which $80-90 \%$ sub-confluence was found to be optimal for cell differentiation, which lasted for two-three weeks. At the beginning of the $3^{\text {rd }}$ week, the lipid droplets enlarged and invaded the entire cytoplasm like adipocyte-differentiated rBM-MSCs (Figure 4Aa-c).

Histo- and immunohistochemical techniques for bonespecific markers were performed to cells grown in osteogenic differentiation medium and also in control medium to assess the osteogenic differentiation of rBM-MSCs. Proliferation and differentiation of both cultures were compared using phase contrast microscopy. Both cells proliferated and reached almost complete confluency after 8-10 days of incubation. Later, the cellular aggregates were observed in osteogenic differentiation cultures and gradually increased. The aggregates were characterized by the presence of amorphous material deposits (Figure 4B-a). These nodular aggregates in osteogenic cultures were stained with Alizarin red $\mathrm{S}$, demonstrating that the amorphous deposits observed under microscope at day 15 were actually calcium deposits (Figure $4 B-b)$. Cells that were incubated for 15 days also strongly stained for BMP4, osteopontin (Figure 4B-C), osteocalcin and BMP2 (data not shown). 

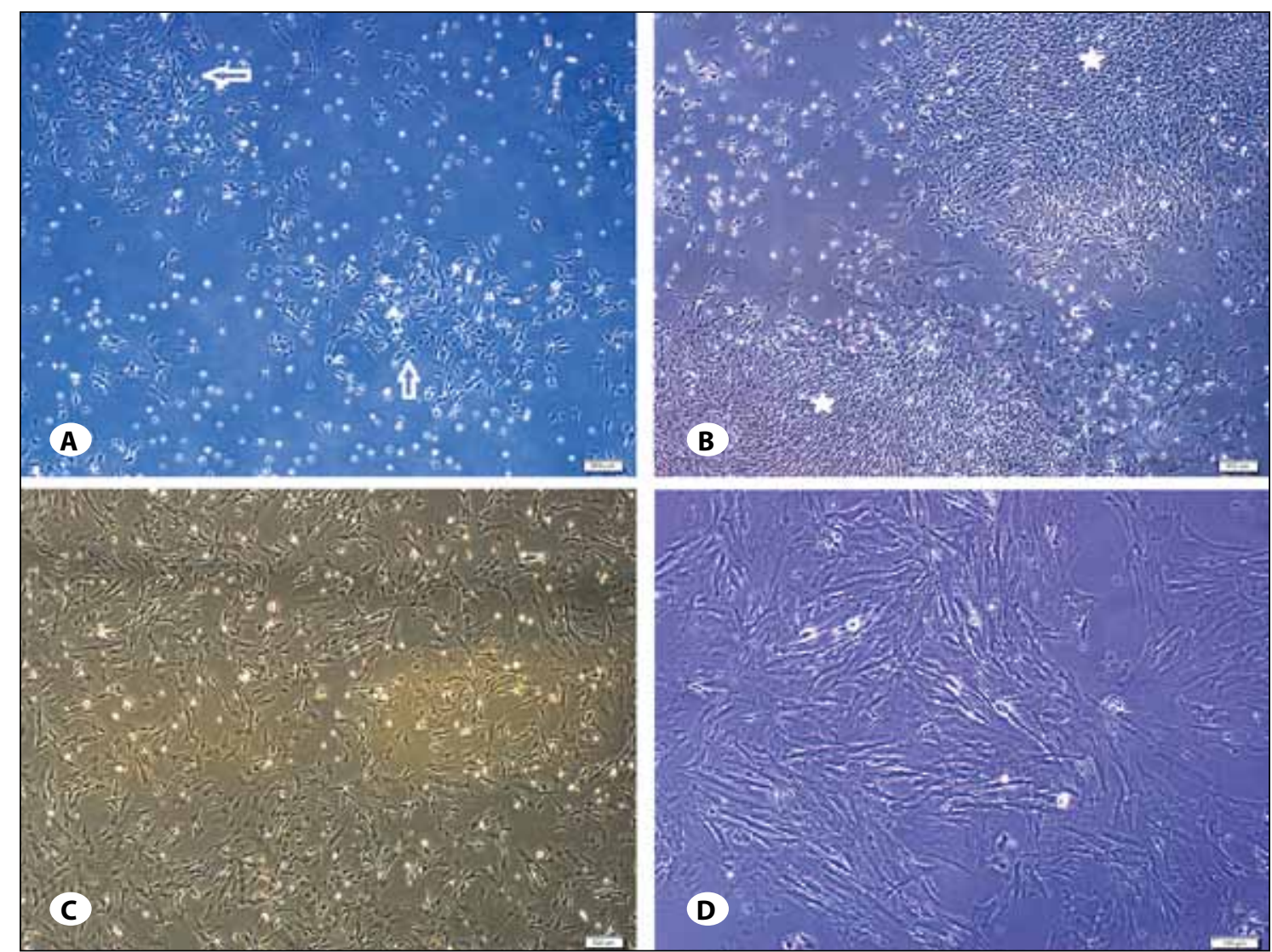

E
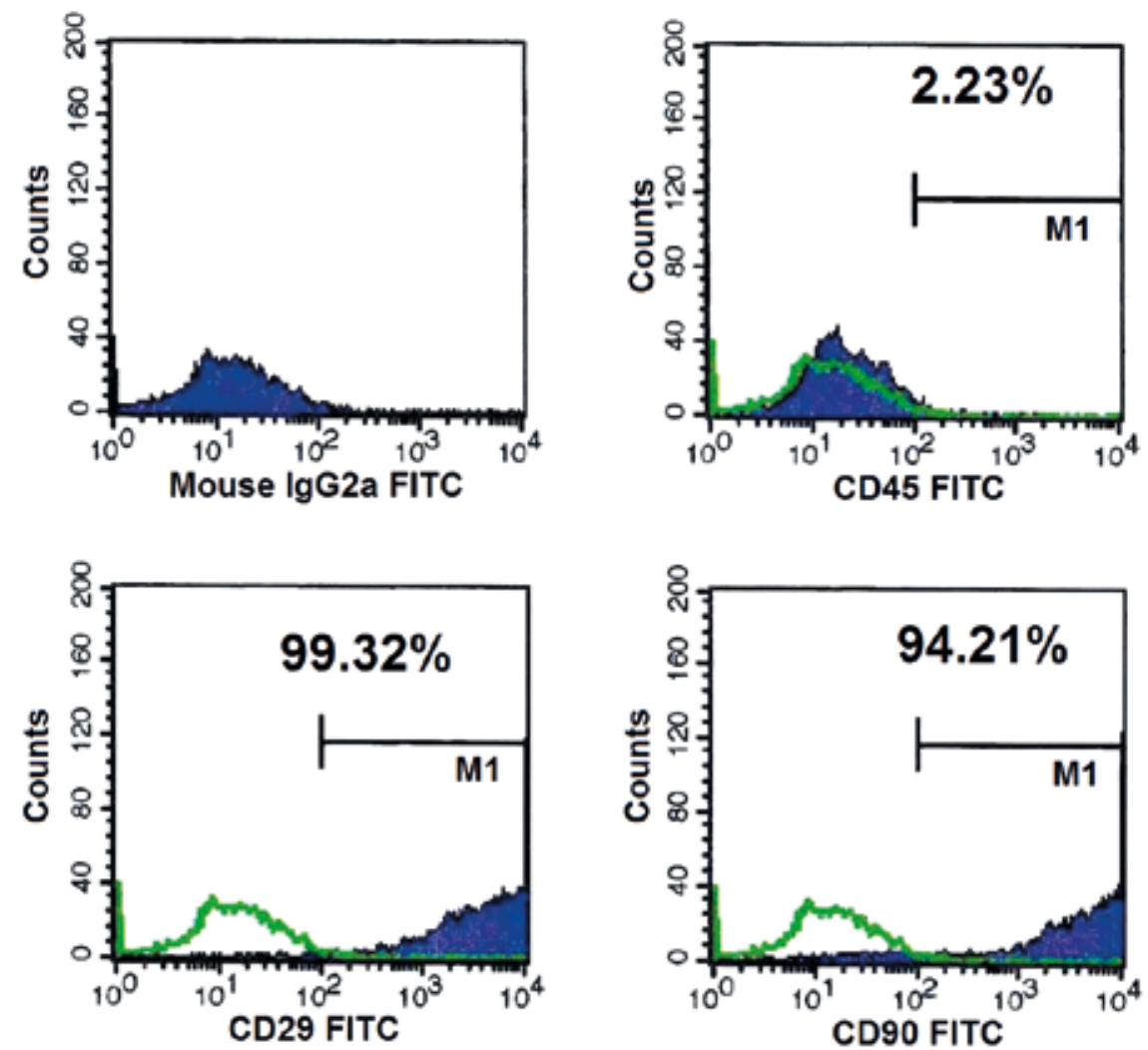

Figure 1: rBM-MSCs morphologies for primary culture (A-B) and late passages (C) P1-3 ${ }^{\text {rd }}$ day; (D) P3-7th day). (E) Flow cytometry analysis for P3 cells. 


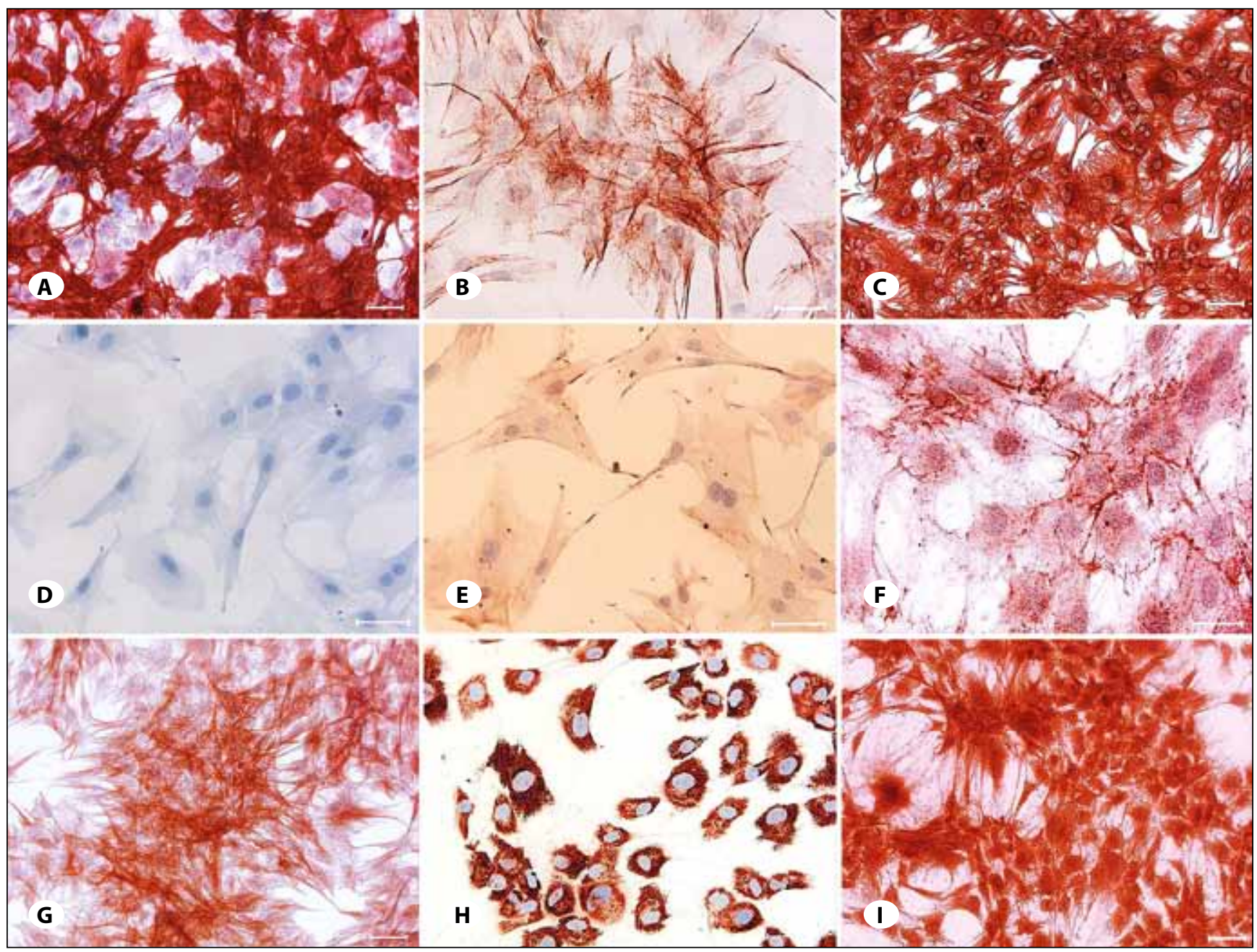

Figure 2: Immunophenotype of rBM-MSCs. Asma (A), beta-tubulin (B), GFAP (C), CD34 (D), beta-actin (E), OCN (F), c-fos (G), type-II collagen (H), and osteonectin (I). (Scale bars, $50 \mu \mathrm{m})$.

\section{Neurogenic differentiation}

rBM-MSCs-derived neuron-like cells displayed distinct morphologies, ranging from extensively simple bipolar to large, branched multipolar cells (Figure 4C-a). To characterize neuronal identity further, differentiated rBM-MSCs were positively stained for some neuron or glial cell specific markers including MAP2a,b (Fig.4C-b), beta-tubulin (Figure 4C-c), c-fos (Figure 4C-c), GFAP, beta3-tubulin, eno2, and HNK-1ST (data not shown).

\section{Survival and migration of rBM-MSCs}

After 4 weeks, the immunofluorescence microscopic analyses of longitudinal and transversal sections of rat spinal cords from experimental groups were performed with double staining of GFP together with either GFAP, beta3-tubulin or c-fos. In all sections of Laminectomy (1) and Laminectomy\&Trauma (2) groups, they showed negative staining for GFP. Noticeably, the center of the lesion was severely cavitated in the Laminectomy\&Trauma group (Figure 5). However, GFP+ cells were observed in the vicinity of the damage site of Group4 at the end of 4 weeks, and most of the surviving cells were located at the periphery of the lesion site next to healthier tissue (Figure 5). GFP+ MSCs migrated into the cavitated area from the injection sites, and the majority still survived and expressed some stem cell and neural markers such as GFAP (Figure 6), vimentin (Figure 7), nestin (data not shown) and beta3-tubulin (Figure 7).

Interestingly, the sections of low scored animals of Group4 in tests showed considerably lower number of GFP+ cells migrated to the damage site than the sections of higher scored animals. Additionally, the increase of GFAP expression in this region was remarkable (Figure 6).

\section{Functional recovery}

To confirm the traumatic impact of the standardized severe weight-drop contusion injury to the T10-T11 spinal cord, the hind limb locomotion of the $\mathrm{SCl}$ rats were evaluated. At each assessment time point, consistent functional deficits were noted among SCI rats with the BBB locomotion scores showing profound loss initially, which then gradually improved and 

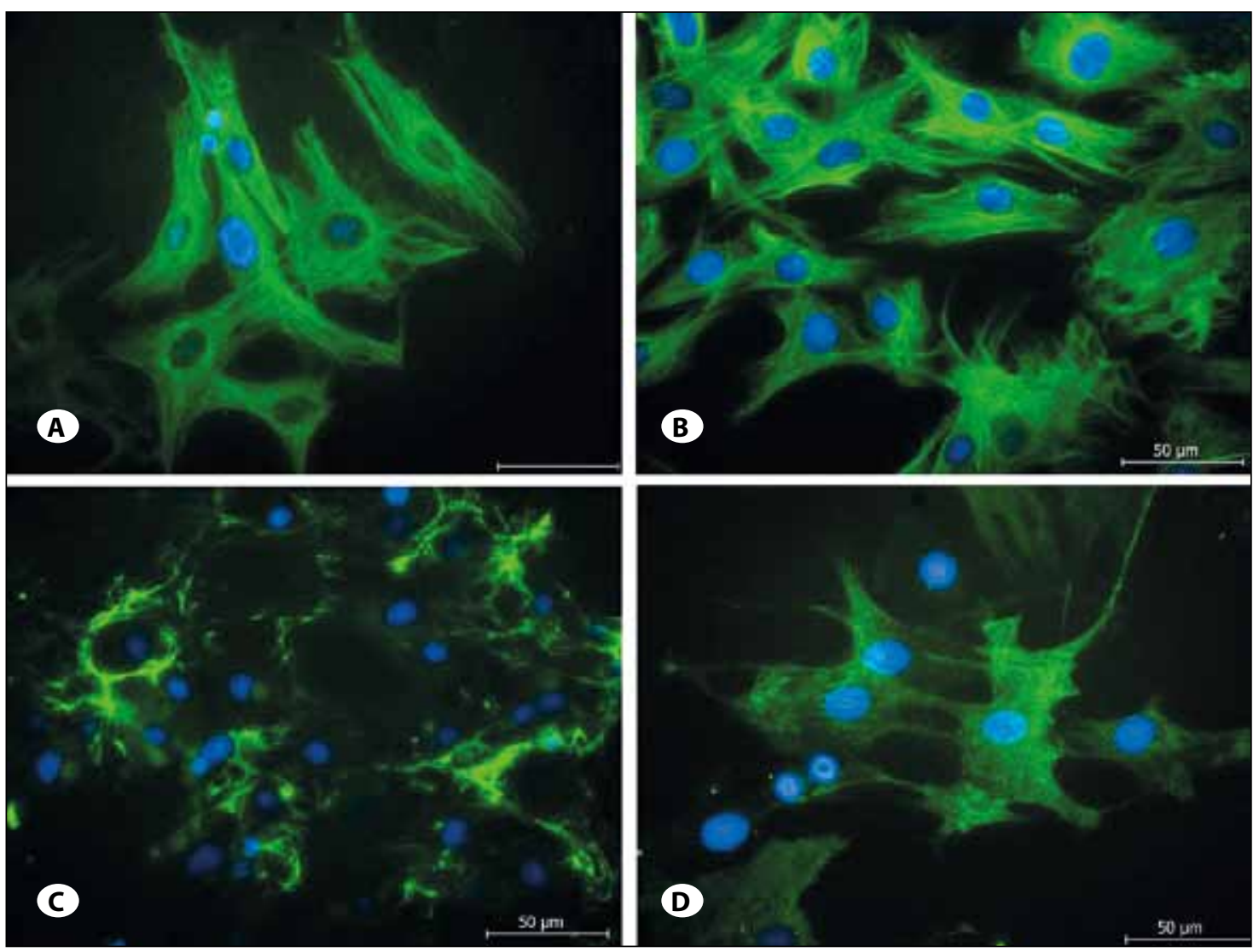

Figure 3:

Expression of protein markers: Beta-tubulin (A), vim (B), fibronectin (C), and beta-actin (D). Nuclei were labeled with DAPI (blue) (Scale bars, $50 \mu \mathrm{m})$.

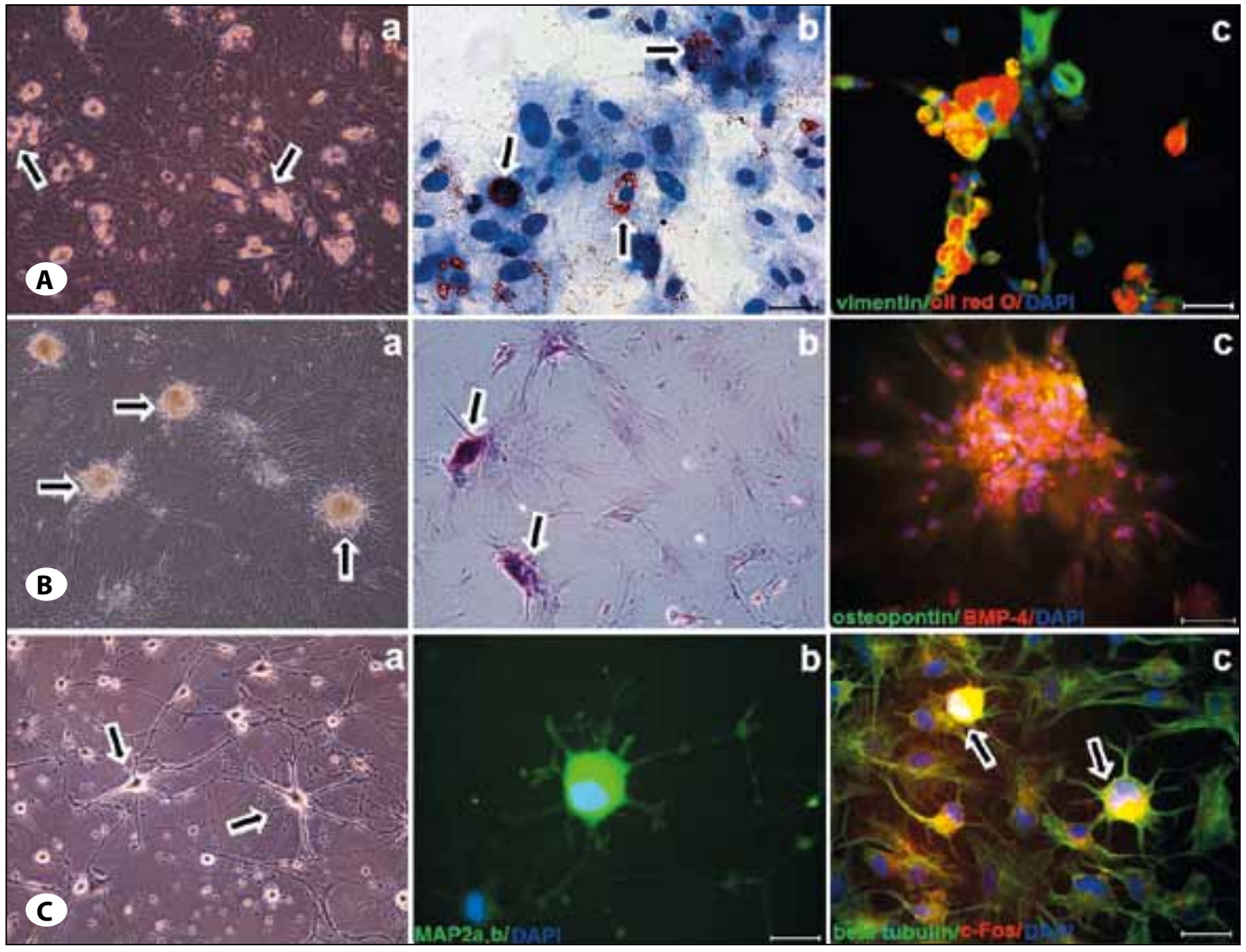

Figure 4:

Differentiation of rBM-MSCs into adipogenic (A), osteogenic (B) and neural (C) lineages. Red-Oil (A-b), AlizarinRed-S stainings (B-b). (Scale bar, $50 \mu \mathrm{m})$. 
approached a plateau level of spontaneous recovery typical for this type of injury by 4 weeks p.i. (Table II, III).

According to the BBB locomotor activity test, the performances of Group4 were statistically different than Group 2 and 3 $(p<0.05$, Table II). The injured rats (Group 2 and 3) showed markedly lower activity score than the mesenchymal stem cell injected group (Group 4) in the BBB locomotor rating score. All experimental groups (Group 2-4) showed BBB locomotion score increase to some extent but the highest scores were observed in the mesenchymal stem cell injected group (Group 4) (Figure 8).

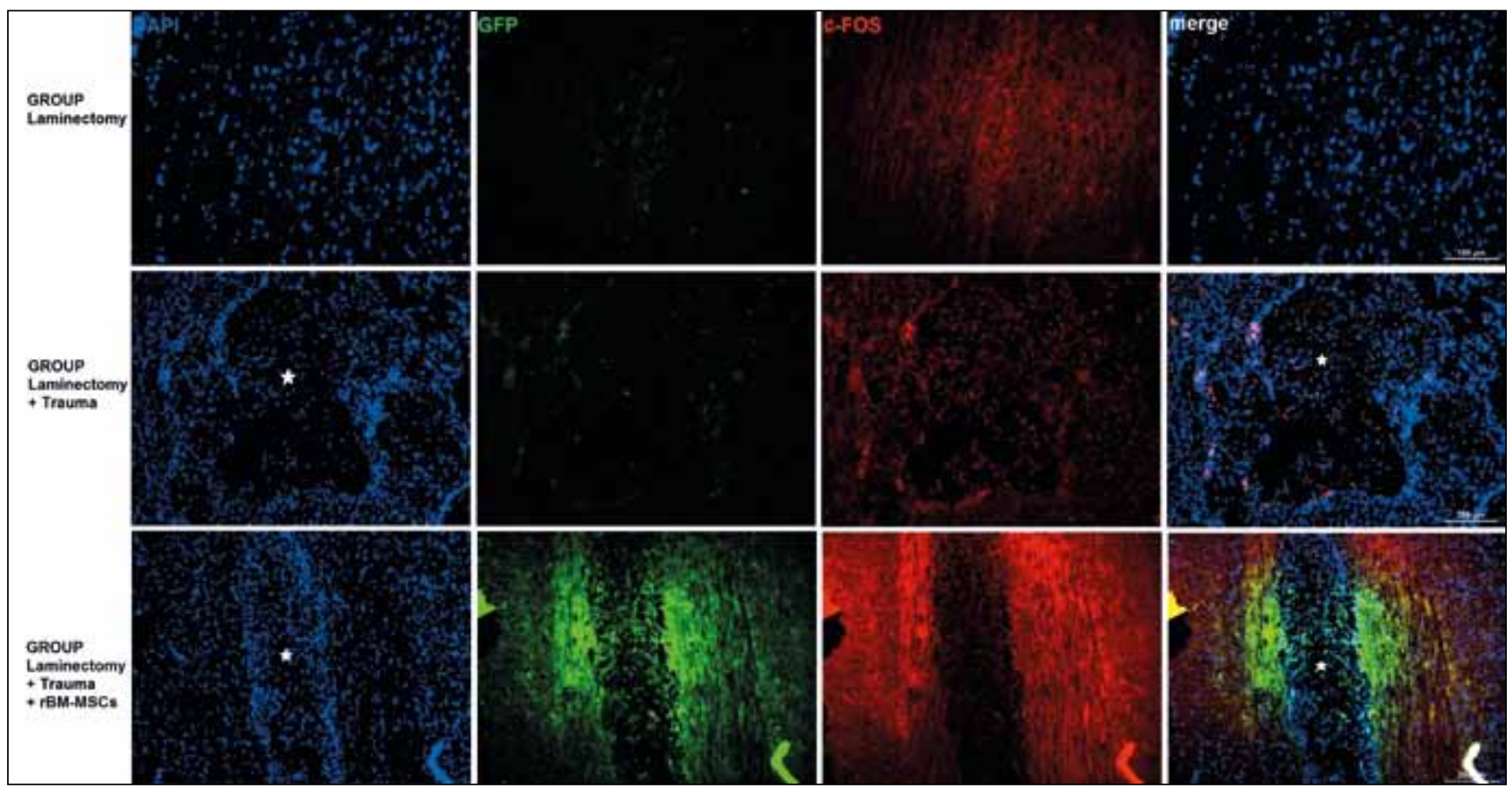

Figure 5: Longitudinal sections of rat spinal cords. After 4 weeks, GFP+ cells were migrated to the damaged site $\left(^{*}\right)$ and survived in Laminectomy\&Trauma\&MSC (Group 4) animals' sections.

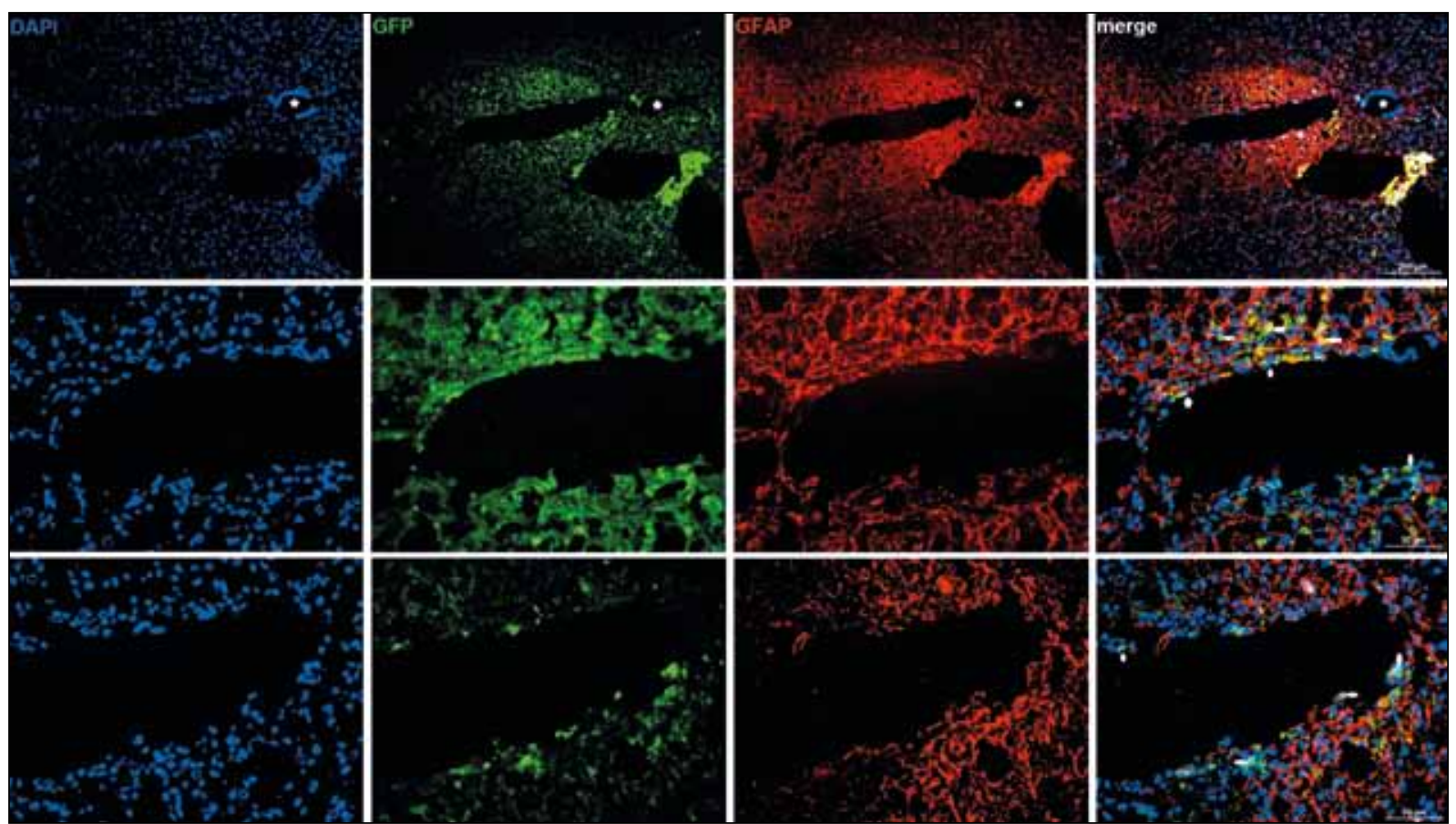

Figure 6: Low-scored animals of Group 4 has lower number of GFP+ cells migrated to the damage site than those of higher scored (arrow). Canalis centralis $\left(^{*}\right)$. 


\section{DISCUSSION}

Different types of stem/progenitor cells have been transplanted into experimental models of spinal cord injury $(\mathrm{SCl})$ with promising results but minimal functional benefit, and phase 1 and 2 trials of stem/progenitor cells have already been performed in humans with $\mathrm{SCl}$ (15). In the present study, we focused on bone marrow derived MSCs because they have the ability to differentiate into neuronal or glial cells both in vitro and in vivo studies $(6,11)$. In addition, BM-MSCs were used because of their easy accessibility, potential for autologous transplantation and promising pre-clinical studies $(3,10,14,22)$. Additionally, BM-MSCs might have advantages over embryonic or fetal stem cells as MSCs have less tumor formation potential and ethical problems.

The general strategy for identifying in vitro cultivated BMMSCs is to analyze the expressions of cell surface markers such as CD29, CD44, CD90 and CD106 $(9,18,22)$. FACS experiments indicated that rBM-MSCs of this study were negative for CD45, a cell surface marker associated with lymphohematopoietic cells. Therefore, there was no evidence of hematopoietic
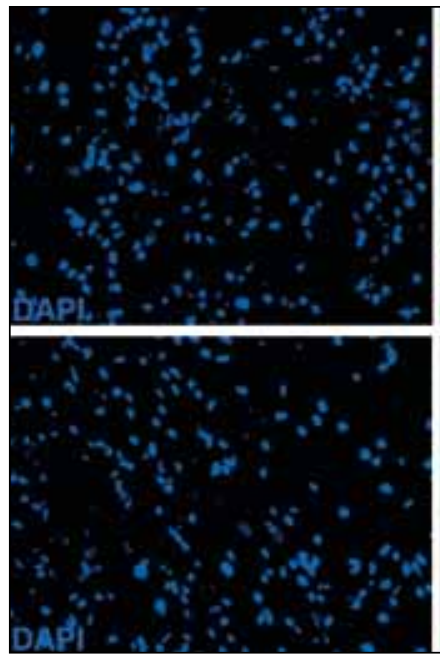
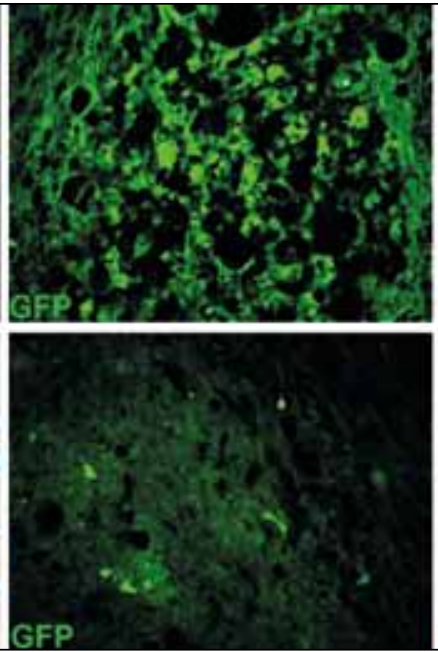
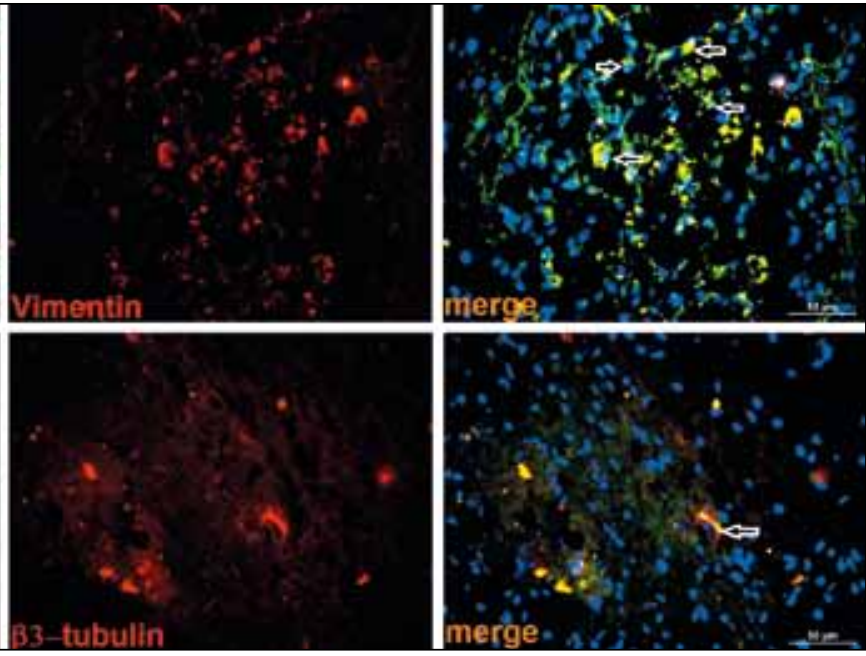

Figure 7: GFP (green), vimentin and beta3-tubulin (red) staining of longitudinal sections of Group 4. GFP+ and vim+ staining could be observed in damage regions and GFP+ and beta3-tub+ in adjacent zone (arrows).

Table II: BBB Scoring for All Groups (mean \pm standard error)

\begin{tabular}{|l|c|c|c|c|} 
& Laminectomy & Laminectomy+Trauma & Laminectomy+Trauma+PBS & Laminectomy+Trauma+MSC \\
\hline & (Group 1) & (Group 2) & (Group 3) & (Group 4) \\
\hline post-op & $21.0 \pm 0.0$ & $1.0 \pm 0.0$ & $1.0 \pm 0.0$ & $2.3 \pm 0.6$ \\
Week 1 & $21.0 \pm 0.0$ & $2.3 \pm 1.2$ & $3.3 \pm 0.6$ & $8.0 \pm 1.0$ \\
Week 2 & $21.0 \pm 0.0$ & $3.4 \pm 1.5$ & $4.3 \pm 0.6$ & $14 \pm 3.6$ \\
\hline Week 3 & $21.0 \pm 0.0$ & $5.6 \pm 2.3$ & $5.3 \pm 1.5$ & $15.3 \pm 2.1$ \\
Week 4 & $21.0 \pm 0.0$ & $9.0 \pm 2.0$ & $8.0 \pm 2.0$ & $16.0 \pm 2.7$
\end{tabular}

Table III: BBB Scores

\begin{tabular}{|c|c|c|c|}
\hline & Mean ( \pm SE) & Min. & Max. \\
\hline Laminectomy (Group1) & $21.00( \pm 0.00)$ & 21.00 & 21.00 \\
\hline Laminectomy \&Trauma (Group2) & $4.26( \pm 3.14)$ & 1.00 & 9.00 \\
\hline Laminectomy\&Trauma\&PBS (Group3) & $4.38( \pm 2.57)$ & 1.00 & 8.00 \\
\hline Laminectomy\&Trauma\&MSC (Group4) & $11.12( \pm 5.85)$ & 2.30 & 16.00 \\
\hline $\begin{array}{l}\text { One way ANOVA (for all groups) (p<0,0 } \\
\text { Laminectomy vs Laminectomy\&Trauma } \\
\text { LaminectomyTrauma vs Laminectomy\&Tr } \\
\text { Laminectomy vs Laminectomy\&Trauma\& } \\
\text { Laminectomy vs Laminectomy\&Trauma\&/ } \\
\text { Laminectomy\&Trauma vs Laminectomy\& } \\
\text { Laminectomy\&Trauma\&PBS vs Laminecto }\end{array}$ & $\begin{array}{l}\text { PBS } \\
\text { \&MSC } \\
\text { auma\&MSC }\end{array}$ & $\begin{array}{ll}p=0.000 & p<0.05 \\
p=1.000 & p>0.05 \\
p=0.000 & p<0.05 \\
p=0.002 & p<0.05 \\
p=0.035 & p<0.05 \\
p=0.037 & p<0.05\end{array}$ & \\
\hline
\end{tabular}




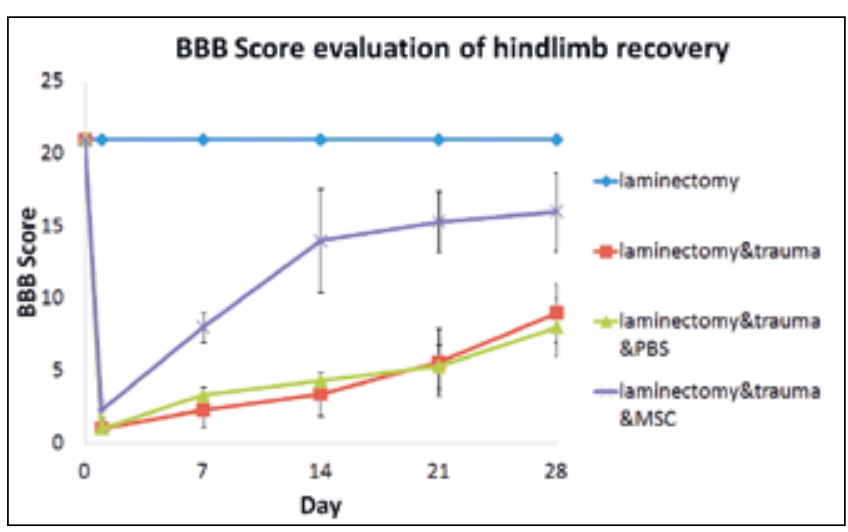

Figure 8: Effect of T10-11 SCl on general hind limb function over time after $\mathrm{SCl}$. Deficits are expressed as a BBB locomotion score.

precursors in the cultures. In contrast, the expression of surface antigens was the same in accordance with the previous reports regarding murine MSCs, indicating that the cells used in this study had the characteristics of MSCs $(1,4)$.

The present study demonstrated that the GFP labeled donor cells survived in the spinal cord injury area. rBM-MSCs were observed around the transplant and on the lesion sites, suggesting migration toward and into the injury, but not rostral or caudal. Besides, there was significant reduction in the cavitation area in the rats receiving BM-MSCs in comparison with Group 2 and 3 only after 4 weeks. $\mathrm{SCl}$ induced high continuous expression of nestin and GFAP in cells from gray and white matter located around the ependymal region of the central canal.

$\mathrm{SCl}$ is associated with the loss of both neurons and glia. Improved functional outcomes after $\mathrm{SCl}$ may be elicited by neuroprotective approaches that limit secondary tissue loss and thus the loss of function. It has been postulated that this neuroprotection may occur as a result of growth factor production by transplanted cells, and this theory is supported by transfection studies with growth factors such as glial cell line derived neurotrophic factor that have been shown to improve functional recovery after stroke in a rodent model (12). The other options may be inhibition of the host immune response and inflammation (20,23), improvement of vascularization (5) and suppression of glial scar formation (23). Alternatively, functional recovery could be elicited by axon growth and neural plasticity-promoting approaches that result in restoration of damaged and formation of new neural circuits that could become involved in functional recovery $(5,8,16)$.

Regarding locomotor activity, most animals were not able to move their hindlimbs or showed only slight movement of their hip and/or knee joints immediately after contusive injury at the T10-11 segment. The locomotor deficits rapidly recovered during the first two weeks regardless of treatment. Animals with rBM-MSCs continuously improved locomotor score even after 3 weeks of injury to the extent where they could regain coordination between the fore- and hindlimbs with almost consistent weight-supported plantar steps (average BBB scale:11). One-Way ANOVA revealed a significant treatment effect over time $(p<0.05)$.

Interestingly, we determined that there was considerably lower number of GFP+ cells migrated to the damage site in the sections of low scored animals of the Laminectomy\& Trauma\&MSC group (Group 4) in tests than those of higher scored ones. The results of function test scoring show parallelism with the number of the labeled cells in the damaged site after 4 weeks. This result show that there is a correlation between cell viability and migration of MSCs towards the damaged area and functional tests. These results suggest that placing rBM-MSCs into the contused spinal cord enhances recovery of open field locomotion and improves quality of the hindlimbs movement during locomotion.

\section{CONCLUSION}

The present study showed that transplantation of rBMMSCs into the contused spinal cord enhances the extent of myelination in the spared white matter and improved locomotor recovery. Transplantation of BM-MSCs might be an effective strategy to improve functional outcomes following traumatic injuries to the spinal cord. Our study further suggests that manipulation of molecular factors governing cell fate decisions during development could influence the fate of BM-MSCs and positively affect the reparative potential of the transplantation therapy. Clinical trials with BM-MSCs in traumatic spinal cord injury might be started since the encouraging results of applications of rBM-MSCs in experimental models bode well for its therapeutic use in injuries of the human spinal cord.

\section{REFERENCES}

1. Basso DM, Beattie MS, Bresnahan JC: A sensitive and reliable locomotor rating scale for open field testing in rats. J Neurotrauma 12: 1-21, 1995

2. Choi H, Liao WL, Newton KM, Onario RC, King AM, Desilets FC, Woodard EJ, Eichler ME, Frontera WR, Sabharwal S, Teng YD: Respiratory abnormalities resulting from midcervical spinal cord injury and their reversal by serotonin $1 \mathrm{~A}$ agonists in conscious rats. J Neurosci 25(18): 4550-4559, 2005

3. Chopp M, Zhang XH, Li Y, Wang L, Chen J, Lu D, Lu M, Rosenblum M: Spinal cord injury in rat: Treatment with bone marrow stromal cell transplantation. Neuroreport 11: 3001-3005, 2000

4. De Macedo Braga LM, Lacchini S, Schaan BD, Rodrigues B, Rosa K, De Angelis K, Borges LF, Irigoyen MC, Nardi NB: In situ delivery of bone marrow cells and mesenchymal stem cells improves cardiovascular function in hypertensive rats submitted to myocardial infarction. J Biomed Sci 15: 365-374, 2008

5. Ding DC, Shyu WC, Chiang MF, Lin SZ, Chang YC, Wang $\mathrm{HJ}$, Su CY, Li H: Enhancement of neuroplasticity through upregulation of beta1-integrin in human umbilical cordderived stromal cell implanted stroke model. Neurobiol Dis 27(3):339-353, 2007 
6. Grove JE, Bruscia E, Krause DS: Plasticity of bone marrowderived stem cells. Stem cells 22 (4):487-500, 2004

7. Joosten EA, Veldhuis WB, Hamers FP: Collagen containing neonatal astrocytes stimulates regrowth of injured fibers and promotes modest locomotor recovery after spinal cord injury. J Neurosci Res 77: 127-142, 2004

8. Kabatas S, Teng YD: Potential roles of the neural stem cell in the restoration of the injured spinal cord: Review of the literature. Review. Turk Neurosurg 20(2): 103-110, 2010

9. Karaoz E, Aksoy A, Ayhan S, Sariboyaci AE, Kaymaz F, Kasap $M$ : Characterization of mesenchymal stem cells from rat bone marrow: Ultrastructural properties, differentiation potential and immunophenotypic markers. Histochem Cell Biol 132: 533-546, 2009

10. Lee J, Kuroda S, Shichinohe H, Ikeda J, Seki T, Hida K, Tada M, Sawada K, Iwasaki Y: Migration and differentiation of nuclear fluorescence-labeled bone marrow stromal cells after transplantation into cerebral infarct and spinal cord injury in mice. Neuropathology 23:169-180, 2003

11. Long $X$, Olszewski $M$, Huang W, Kletzel M: Neural cell differentiation in vitro from adult human bone marrow mesenchymal stem cells. Stem Cells Dev 14(1):65-69, 2005

12. Parr AM, Kulbatski I, Wang $\mathrm{XH}$, Keating $\mathrm{A}$, Tator $\mathrm{CH}$ : Fate of transplanted adult neural stem/progenitor cells and bone marrow-derived mesenchymal stromal cells in the injured adult rat spinal cord and impact on functional recovery. Surg Neurol 70: 600-607, 2008

13. Parr AM, Kulbatski I, Zahir T, Wang X, Yue C, Keating A, Tator $\mathrm{CH}$ : Transplanted adult spinal cord-derived neural stem/ progenitor cells promote early functional recovery after rat spinal cord injury. Neuroscience 155: 760-770, 2008

14. Parr AM, Tator $\mathrm{CH}$, Keating A: Bone marrow-derived mesenchymal stromal cells for the repair of central nervous system injury. Bone Marrow Transplant 40:609 - 619, 2007

15. Tator $\mathrm{CH}$ : Review of treatment trials in human spinal cord injury: Issues, difficulties, and recommendations. Neurosurgery 59:957-982, 2006
16. Teng YD, Liao WL, Choi H, Konya D, Sabharwal S, Langer R, Sidman RL, Snyder EY, Frontera WR: Physical activity-mediated functional recovery after spinal cord injury: Potential roles of neural stem cells. Review. Regen Med 1: 763-776, 2006

17. Teng YD, Wrathall JR: Local blockade of sodium channels by tetrodotoxin ameliorates tissue loss and long-term functional deficits resulting from experimental spinal cord injury. J Neurosci 17(11): 4359-4366, 1997

18. Tobias CA, Han SS, Shumsky JS, Kim D, Tumolo M, Dhoot NO, Wheatley MA, Fischer I, Tessler A, Murray M: Alginate encapsulated BDNF-producing fibroblast grafts permit recovery of function after spinal cord injury in the absence of immune suppression. J Neurotrauma 22: 138-156, 2005

19. Weiss ML, Medicetty S, Bledsoe AR, Rachakatla RS, Choi M, Merchav S, Luo Y, Rao MS, Velagaleti G, Troyer D: Human umbilical cord matrix stem cells: Preliminary characterization and effect of transplantation in a rodent model of Parkinson's disease. Stem Cells 24(3):781-792, 2006

20. Widenfalk J, Lundströmer K, Jubran M, Brene S, Olson L: Neurotrophic factors and receptors in the immature and adult spinal cord after mechanical injury or kainic acid. J Neurosci 21: 3457-3475, 2001

21. Wu S, Suzuki Y, Ejiri Y, Noda T, Bai H, Kitada M, Kataoka K, Ohta $M$, Chou $H$, Ide $C$ : Bone marrow stromal cells enhance differ-entiation of cocultured neurosphere cells and promote regeneration of injured spinal cord. J Neurosci Res 72: 343-351, 2003

22. Xie F, Zheng B: White matter inhibitors in CNS axon regeneration failure. Exp Neurol 209: 302-312, 2008

23. Yang CC, Shih YH, Ko MH, Hsu SY, Cheng H, Fu YS: Transplantation of human umbilical mesenchymal stem cells from Wharton's jelly after complete transection of the rat spinal cord. PLoS One 3(10):e3336, 2008 